\title{
PROBIOTIK Bacillus cereus UNTUK PENGENDALIAN PENYAKIT Streptococcosis PADA IKAN NILA, Oreochromis niloticus
}

\author{
Angela Mariana Lusiastuti*), Sari Dwi Maryanti"*), dan Uni Purwaningsih") \\ *) Balai Penelitian dan Pengembangan Budidaya Air Tawar \\ Jl. Sempur No. 1, Bogor 16154 \\ E-mail: lusiastuti@yahoo.com \\ **) Mahasiswa Fakultas Perikanan dan IImu Kelautan, Universitas Padjajaran \\ Jl. Raya Bandung Sumedang KM 21, Jatinangor 40600, Bandung, Jawa Barat
}

(Naskah diterima: 5 April 2012; Disetujui publikasi: 6 Februari 2013)

\begin{abstract}
ABSTRAK
Penelitian ini bertujuan untuk mengetahui peran probiotik Bacillus cereus terhadap ketahanan benih ikan air tawar yaitu ikan nila (O. niloticus) yang diinfeksi Streptococcus agalactiae. Metode yang digunakan dalam penelitian ini adalah metode eksperimental Rancangan Acak Lengkap (RAL) dengan empat perlakuan dan tiga ulangan yang diaplikasikan melalui pakan. Perlakuan tersebut adalah A (tanpa penambahan probiotik B. cereus dan prebiotik), perlakuan B (penambahan probiotik B. cereus sebesar 1\%), perlakuan $C$ (penambahan prebiotik $2 \%$ ), dan perlakuan D (penambahan sinbiotik; probiotik B. cereus $1 \%$ dan prebiotik $2 \%$ ). Parameter yang diamati adalah tingkat sintasan ikan uji pada saat uji tantang, indeks fagositik, differensial leukosit, dan kualitas air. Analisis data tingkat sintasan dilakukan dengan menggunakan uji $\mathrm{F}$ dengan taraf signifikansi 5\%. Indeks fagositik, differensial leukosit dan kualitas air dianalisis secara deskriptif. Hasil penelitian menunjukkan penambahan $1 \%$ probiotik B. cereus dan $2 \%$ prebiotik (ekstrak tepung ubi jalar) yang dicampurkan ke dalam pakan komersial (sinbiotik) dapat meningkatkan rata-rata sintasan ikan nila sebesar $70 \%$, kadar neutrofil 19\%, dan aktivitas fagosit sebesar 51,5\% setelah diuji tantang dengan Streptococcus agalactiae dan lebih baik jika dibandingkan dengan kontrol, probiotik, dan prebiotik saja dengan tingkat sintasan masing-masing 48,33\%; 56,67\%; dan $60 \%$.
\end{abstract}

KATA KUNCl: Bacillus cereus, Streptococcus agalactiae, prebiotik, nila

ABSTRACT: Probiotic Bacillus cereus for streptococcosis disease control in tilapia Oreochromis niloticus. By: Angela Mariana Lusiastuti, Sari Dwi Maryanti, and Uni Purwaningsih

This study aims to determine the activity of probiotic Bacillus cereus against Streptococcus agalactiae in tilapia (O. niloticus). The method used in this study is an experimental completely random design with four treatments and three replications. The treatment is control $A$ (without addition of probiotic $B$. cereus and prebiotic), treatment $B$ (addition of probiotic B. cereus $1 \%$ ), treatment $C$ (the addition of prebiotic 2\%), and treatment $D$ (the addition of synbiotic (probiotic B. cereus $1 \%$ and prebiotic 2\%), Parameters observed are the survival rates of test fish during the challenge test, phagocytic index, leucocyte differential, and water quality. Data analysis was performed with the survival rate using the $F$ test with a level of $5 \%$. Phagocytic index, leucocyte differential, and the quality of water are analysis in descriptive. The results showed that the addition of $1 \%$ probiotic B. cereus and $2 \%$ prebiotics (extract of sweet potato flour) are mixed into the commercial feed (synbiotic) 
can increase the average survival of $70 \%$ tilapia, neutrofil $19 \%$, and phagocyte activity $51.5 \%$ after challenge test and more better than control, probiotic and prebiotic only with survival rate $48.33 \%$; $56.67 \%$; and $60 \%$.

\section{KEYWORDS: Bacillus cereus, Streptococcus agalactiae, prebiotic, tilapia}

\section{PENDAHULUAN}

Ikan nila (O. niloticus) merupakan jenis ikan air tawar yang memiliki keunggulan yang menguntungkan. Pertumbuhan yang sangat cepat, mudah dipelihara, tahan terhadap kondisi air yang buruk, memiliki nilai gizi, dan nilai ekonomis yang cukup tinggi (Sumiarti, 2000). Ikan nila (O. niloticus) sudah lama dikenal oleh masyarakat luas sebagai ikan konsumsi, mengandung nutrisi yang hampir sama dengan jenis ikan air tawar lainnya. Nila merupakan ikan yang banyak diminati masyarakat sebagai sumber protein hewani dengan kandungan gizi 17,7\% protein dan 1,3\% lemak (Rukmana, 1997 dalam Sumiarti, 2000). Ikan nila mulai dikembangkan di masyarakat dengan tujuan untuk meningkatkan komoditi perikanan dan pemenuhan kebutuhan protein hewani. Potensi pasar ikan nila termasuk cukup prospektif. Permintaan pasar internasional ikan nila mencapai 200.000 ton/tahun (Sumiarti, 2000). Untuk memenuhi permintaan pasar tersebut maka budidaya nila dilakukan secara intensif dengan padat penebaran yang tinggi serta pemberian pakan yang berlebihan. Kondisi tersebut dapat memicu timbulnya berbagai penyakit yang disebabkan oleh bakteri patogen.

Penyakit yang banyak menginfeksi ikan nila adalah Streptoccocosis yang disebabkan oleh bakteri S. agalactiae (Chang \& Plumb, 1996). Streptococcosis akibat infeksi Streptococcus merupakan penyakit pada tilapia yang biasa dihadapi petani ikan dalam usaha budidaya dan dapat menyebabkan kematian ikan yang tinggi (Baya et al., 1990).

Berbagai cara telah berhasil dilakukan untuk mengendalikan infeksi bakterial pada ikan baik secara kuratif (pengobatan) maupun preventif (pencegahan). Penggunaan antibiotik dan bahan kimia dapat digunakan untuk menanggulangi infeksi bakterial, Namun, dalam penggunaan zat kimia tersebut dapat menimbulkan resistensi pada ikan dan juga dapat membahayakan manusia sebagai konsumen. Saat ini telah banyak dikembangkan metode lain yang lebih aman dan efektif, salah satu- nya adalah dengan penggunaan probiotik. Probiotik adalah agen mikroba hidup yang mampu memberikan keuntungan bagi inang yakni dengan memodifikasi komunitas mikroba atau berasosiasi dengan inang, memperbaiki nilai nutrisi, dan pemanfaatan pakan, meningkatkan respons inang terhadap penyakit, dan memperbaiki kualitas lingkungan (Verschuere et al., 2000).

Bacillus cereus merupakan bakteri probiotik yang diisolasi dari usus ikan nila (Lusiastuti et al., 2011). Short et al. (1999) mengemukakan bahwa kriteria yang perlu dipertimbangkan untuk mendapatkan probiotik dengan pengaruh positif yang optimal bagi inangnya antara lain memiliki jumlah sel hidup dengan kepadatan $10^{7}-10^{9} \mathrm{CFU} / \mathrm{mL}$. Namun, sejauh ini belum ada informasi mengenai dosis probiotik $B$. cereus yang efektif dan dapat meningkatkan ketahanan pada benih ikan nila. Penelitian ini bertujuan untuk mengetahui kualitas dan dosis yang tepat dari probiotik $B$. cereus yang diaplikasikan lewat pakan terhadap ketahanan benih ikan nila yang diinfeksi oleh S. agalactiae.

\section{BAHAN DAN METODE}

Ikan uji yang digunakan dalam penelitian ini adalah benih ikan nila BEST dengan bobot 15-20 g sebanyak 800 ekor berasal dari kolam pembenihan nila di Instalasi Riset Lingkungan Perikanan Budidaya dan Toksikologi, Cibalagung. Ikan dipelihara dalam akuarium dengan kepadatan 10 ekor/akuarium. Ukuran ikan 6-7 cm dan volume air 20 liter. Probiotik yang digunakan adalah $B$. cereus yang diisolasi dari usus ikan nila, yang dicampur dengan pakan komersial sebesar $1 \%$ (1 g probiotik/100 g pakan) (Wang et al., 2008), 2\% prebiotik berupa tepung ubi jalar $(2 \mathrm{~g}$ tepung $/ 100 \mathrm{~g}$ pakan) dicampurkan dengan $1 \%$ probiotik $B$. cereus dalam pakan komersial (sinbiotik) (Mahious et al., 2006). Pakan komersial berupa pelet terapung dengan kadar protein 31\%-33\%.

Metode yang digunakan dalam penelitian ini adalah eksperimen dengan rancangan acak lengkap yang terdiri atas 4 perlakuan dan 3 kali pengulangan yaitu: 

$A=$ Pemberian pakan tanpa penambahan probiotik dan prebiotik (kontrol)
$\mathrm{B}=$ Pemberian pakan dengan penambahan probiotik B. cereus sebesar $1 \%(1 \mathrm{~g} / 100 \mathrm{~g}$ pakan (Wang et al., 2008)
$\mathrm{C}=$ Pemberian pakan dengan penambahan prebiotik sebesar $2 \%$ ( $2 \mathrm{~g} / 100 \mathrm{~g}$ pakan)
$\mathrm{D}=$ Pemberian pakan dengan penambahan sinbiotik ( $1 \%$ probiotik $+2 \%$ prebiotik)

\section{Penyiapan dan Pencampuran Probiotik B. cereus dalam Pakan}

Satu ose $B$. cereus dimasukkan ke dalam media TSB volume $25 \mathrm{~mL}$ selanjutnya dikultur pada shaker bergoyang selama 24 jam pada suhu $29^{\circ} \mathrm{C}$. Bakteri dipanen dan disentrifus selama 15 menit pada kecepatan $5.000 \mathrm{rpm}$. Endapan (pelet) ditambahkan $25 \mathrm{~mL}$ PBS dan di-mixer. Kemudian disentrifus lagi selama 10 menit dengan kecepatan $5.000 \mathrm{rpm}$. Perlakuan ini dilakukan sampai dua kali sehingga $B$. cereus siap digunakan. Pakan komersial disiapkan sebanyak $10 \mathrm{~g}$ dan $B$. cereus dilarutkan dalam PBS ( $1 \%$ dari $10 \mathrm{~g}$ pakan) yaitu $0,1 \mathrm{~g}$ atau $0,1 \mathrm{~mL}$ probiotik dan kuning telur ( $2 \%$ dari $10 \mathrm{~g}$ pakan) yaitu $0,2 \mathrm{~g}$. Kuning telur $0,2 \mathrm{~g}$; $B$. cereus $0,1 \mathrm{~mL}$; dan pakan komersial sebanyak $10 \mathrm{~g}$ dicampur ke dalam mortar dan diaduk sampai merata. Penyiapan ini untuk satu akuarium. Hal ini dilakukan sebanyak 3 kali untuk 3 akuarium dengan perlakuan penambahan probiotik.

\section{Penyiapan dan Pencampuran Prebiotik Tepung Ubi Jalar dan Probiotik (Sinbi- otik)}

Tepung ubi jalar sebanyak $50 \mathrm{~g}$ dilarutkan dalam $500 \mathrm{~mL}$ alkohol 70\% dalam erlenmeyer. Dihomogenkan dengan magnetic stirrer selama 24 jam lalu disaring dengan kertas saring (Whatman No. 41). Hasil saringan dipekatkan dengan evaporator vaccum selama 1 jam. Prebiotik siap dipakai dan dicampurkan dalam pakan. Kuning telur sebanyak $0,2 \mathrm{~g} \mathrm{di-}$ campur prebiotik tepung ubi jalar $0,2 \mathrm{~mL}$ dan B. cereus $0,1 \mathrm{~mL}$; serta pakan komersial $10 \mathrm{~g}$ dimasukkan ke dalam mortar dan dicampur merata. Hal ini dilakukan sebanyak 3 kali untuk 3 akuarium perlakuan dengan penambahan sinbiotik.

Penyiponan dasar wadah pemeliharaan ikan dilakukan setiap 2 hari sekali untuk membuang sisa pakan dan feses. Penggantian air media sebesar $20 \%$ dari total volume air media pemeliharaan pada waktu dilakukan penyiponan. Pengujian kualitas air dilakukan pada awal (hari ke-1), hari ke-7, dan hari ke-14 selama masa pemeliharaan.

\section{Uji Tantang}

Setelah dilakukan masa pemeliharaan selama 14 hari, pada hari ke-15 dilakukan uji tantang terhadap benih ikan nila. Infeksi buatan dilakukan melalui teknik penyuntikan secara intramuscular (IM) dengan dosis $S$. agalactiae $0,1 \mathrm{~mL} /$ ekor pada konsentrasi $10^{5}$ $\mathrm{CFU} / \mathrm{mL}$ yang merupakan dosis $\mathrm{LD}_{50}$ (Taukhid, 2009). Pengamatan dilakukan setiap 6 jam/hari pada pukul 08.00 , pukul 14.00 , dan pukul 20.00 , terhadap gejala klinis dan sintasan (SR) benih ikan nila hingga hari ke-14 setelah proses infeksi. Pengamatan dihentikan manakala ikan uji mati secara keseluruhan meskipun belum mencapai 14 hari. Pada masa uji tantang, tidak dilakukan penyiponan agar bakteri S. agalactiae tidak terbuang bersama air yang diganti. Pemberian pakan dilakukan seperti pada masa pemeliharaan ikan sebelum uji tantang.

Parameter yang diamati adalah gejala klinis dari efek penggunaan probiotik dan uji tantang, differensial leukosit, dan indeks fagositosis.

\section{Gejala Klinis}

Gejala klinis yang diamati adalah kerusakan permukaan tubuh (gejala klinis eksternal) dan tingkah laku ikan yang mencakup respons terhadap pakan uji. Pengamatan tersebut dilakukan saat uji tantang sampai akhir penelitian.

\section{Differensial Leukosit}

Pengamatan differensial leukosit dilakukan sebanyak tiga kali sampling yaitu sebelum pemberian probiotik, pasca pemberian probiotik B. cereus, dan pada hari ke-7 setelah uji tantang. Pengamatan dilakukan untuk mengetahui perubahan jumlah total leukosit yang berkaitan dengan respons kekebalan tubuh ikan pada saat pemberian probiotik dan setelah uji tantang.

\section{Indeks Fagositosis}

Pengamatan indeks fagositosis dilakukan sebanyak tiga kali yaitu sebelum pemberian probiotik, saat pemberian probiotik $B$. cereus dan pada hari ke-7 dan ke-14 setelah uji tantang. Pengamatan pada saat perlakuan $B$. 
cereus untuk mengetahui peningkatan sel fagosit, dan pengamatan pada setelah uji tantang untuk mengetahui kemampuan leukosit dalam melakukan mekanisme fagositosis saat diinjeksi S. agalactiae.

\section{Analisis Data}

Pengaruh perlakuan terhadap tingkat sintasan pada ikan uji dianalisis dengan analisis sidik ragam dengan uji $F$, apabila terdapat perbedaan nyata antar perlakuan dianalisis dengan uji jarak Duncan dengan taraf 5\% (Gasperz et al., 1991) dan untuk mengetahui hubungan masing-masing perlakuan dengan sintasan dianalisis dengan analisis regresi. Adapun hasil pengamatan gejala klinis, differensial leukosit, indeks fagositosis, dan kualitas air dianalisis secara deskriptif.

\section{HASIL DAN BAHASAN}

\section{Sintasan}

Rata-rata tingkat sintasan ikan uji sebelum dilakukan uji tantang dengan S. agalactiae, pada 4 perlakuan selama dua minggu pengamatan adalah sebesar 99\%-100\%.

Hasil pengamatan setelah dilakukan uji tantang dengan S. agalactiae pada ikan nila, rata-rata tingkat sintasan ikan uji selama dua minggu pengamatan menunjukkan hasil yang bervariasi pada setiap perlakuan. Rata-rata sintasan ikan nila setelah diuji tantang dengan S. agalactiae sebesar $48,33 \%-70,00 \%$.

Selama masa pemeliharaan 7 hari setelah diinfeksi S. agalactiae, perlakuan kontrol (A) menunjukkan persentase rata-rata sintasan paling rendah, yaitu sebesar $48,33 \%$ (Gambar 1). Pada ikan uji dengan penambahan probiotik $B$. cereus (B) dalam pakan, penambahan prebiotik ekstrak tepung ubi jalar $2 \%$ (C) dan sinbiotik (D) memperlihatkan mortalitas yang lebih rendah dibandingkan dengan ikan kontrol (A). Perlakuan dengan tambahan sinbiotik yaitu campuran antara probiotik sebanyak $1 \%$ dan prebiotik sebanyak $2 \%$ (D) memberikan mortalitas terendah di antara perlakuan yang lainnya, sehingga memberikan sintasan tertinggi yaitu sebesar 70,00\%.

Sintasan ikan nila yang tidak diberi perlakuan (A) menghasilkan sintasan paling rendah $(48,33 \%)$ setelah diuji tantang dengan $S$. agalactiae. Kondisi ini memperlihatkan ketahanan ikan nila yang rendah terhadap serangan S. agalactiae. Kemungkinan hal ini terjadi karena ketahanan ikan tidak distimulasi oleh probiotik yang berperan sebagai immunostimulan, sehingga dalam mempertahankan serangan S. agalactiae ikan nila hanya menggunakan pertahanan alami dalam kondisi normal sehingga tidak mampu dalam mempertahankan serangan S. agalactiae yang lebih kuat.

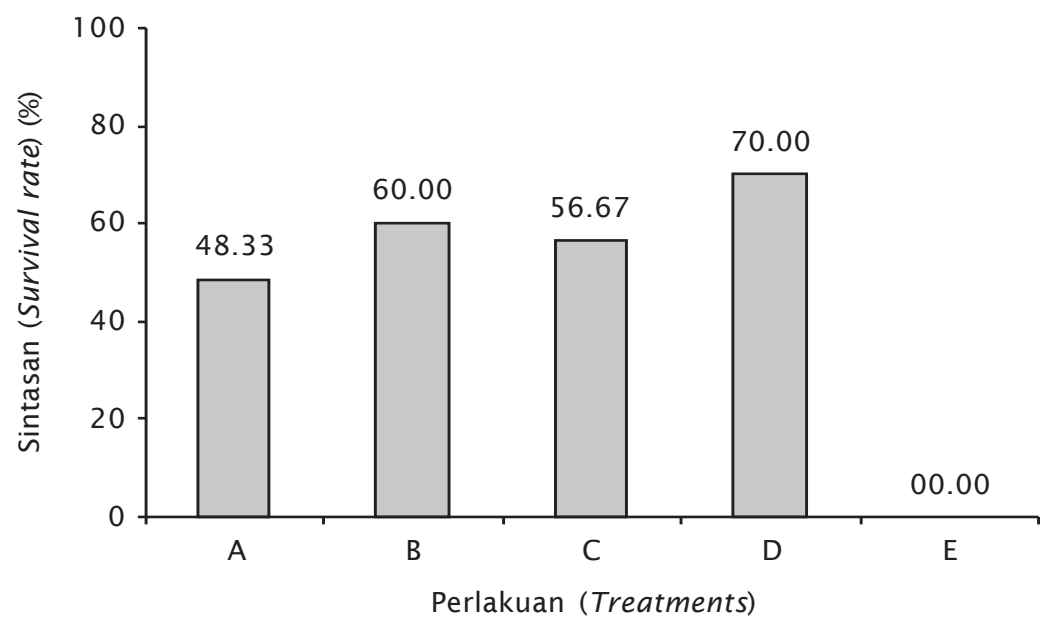

Gambar 1. Sintasan ikan nila (O. niloticus) setelah uji tantang pada pemberian probiotik dari setiap perlakuan

Figure 1. The survival rate of tilapia (O. niloticus) after challenge test on each treatment 
Berdasarkan hasil pengamatan terlihat bahwa ikan dengan perlakuan penambahan sinbiotik (D) paling baik dan tepat dalam menanggulangi infeksi S. agalactiae dengan nilai sintasan tertinggi sebesar $70,00 \%$ dan kadar neutrofil tertinggi yaitu 31,5\%. Berdasarkan perhitungan analisis ragam disimpulkan bahwa penambahan sinbiotik berbeda terhadap ikan perlakuan kontrol (A) namun tidak berpengaruh terhadap ikan uji dengan perlakuan penambahan probiotik $B$. cereus $1 \%$ (B) dan ikan dengan penambahan prebiotik ekstrak tepung ubi jalar 2\% (C). Maka pemberian sinbiotik ini dinilai efektif penggunaannya dibandingkan dengan perlakuan kontrol.

\section{Differensial Leukosit}

Persentase jenis-jenis leukosit yang berperan dalam sistem ketahanan tubuh yaitu limfosit, monosit, dan neutrofil (Gambar 2). Tiga jenis sel ini merupakan bentuk dari leukosit yang berperan dalam merespons kekebalan terhadap antigen (partikel asing) dalam darah.

Berdasarkan hasil pengamatan terhadap differensial leukosit ikan uji selama masa pengamatan setelah uji tantang (Tabel 1),

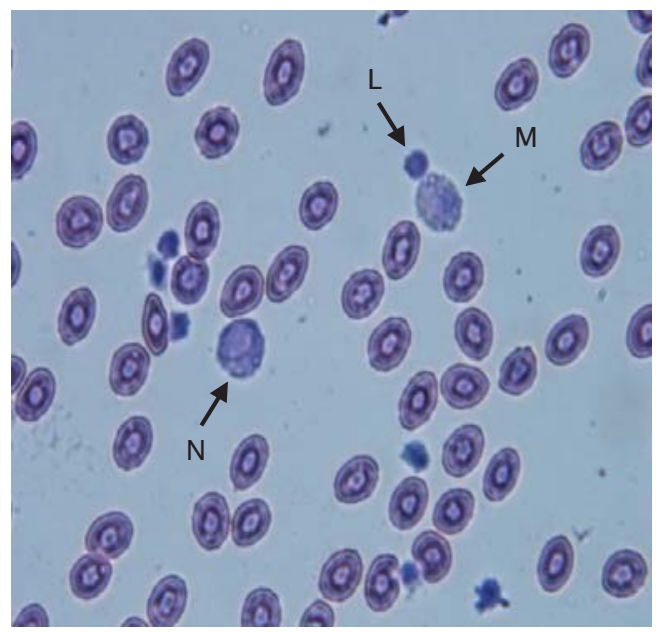

Keterangan (Remark):

Neutrofil (N), limfosit (L), dan monosit (M) (Neutrofil (N), lymphosit (L), and monocyte $(M))$

Gambar2. Gambaran sel darah ikan nila $(O$. niloticus) pada perlakuan A sampai $D$

Figure 2. Blood cells of tilapia (O. niloticus) after treated by different treatment and challenge test proporsi jumlah limfosit menunjukkan jumlah yang paling banyak dibandingkan dengan jumlah monosit dan neutrofil. Namun, setelah dilakukan penginfeksian terhadap ikan uji dengan S. agalactiae didapatkan peningkatan jumlah proporsi neutrofil yang menunjukkan bahwa ikan uji terserang S. agalactiae. Peningkatan jumlah neutrofil diasumsikan menjadi respons terhadap bakteri merugikan yang masuk dan menyerang tubuh ikan uji. Neutrofil berperan dalam merespons infeksi yang diakibatkan oleh bakteri sehingga persentasenya akan meningkat (Purwanto, 2006).

Standar jumlah leukosit ikan nila ( $O$. niloticus) $3.390-14.200 / \mathrm{mm}^{3}$ dengan neutrofil 3,25\%-8,40\%; eosinofil 2,40\%-8,00\%; limfosit 60,20\%-81,00\%; dan monosit 7,75\%-29,20\% (Salasia et al., 2001). Berdasarkan standar persentase proporsi ikan nila maka dapat dilihat terjadi peningkatan proporsi jumlah neutrofil ikan nila yang telah diberi perlakuan (selama masa induksi) dan terjadi peningkatan yang tinggi pada saat dilakukan pengamatan setelah ikan nila diuji tantang dengan $S$. agalactiae (Tabel 2).

Ketahanan tubuh ikan nila terhadap infeksi S. agalactiae lebih rendah pada perlakuan penambahan probiotik (B) dan pada penambahan prebiotik (C) dilihat dari proporsi neutrofil yang jumlahnya lebih rendah dibandingkan perlakuan penambahan sinbiotik (D). Penambahan probiotik ditambah dengan prebiotik dalam pakan (D) memberikan sintasan yang lebih tinggi dibandingkan dengan perlakuan lainnya. Hal ini diperkuat bahwa probiotik $B$. cereus yang dikombinasikan dengan prebiotik mampu memicu ketahanan tubuh lebih baik yang terlihat dengan jumlah neutrofil yang tinggi yaitu sebesar $31,5 \%$ (Tabel 1). Hal ini disebabkan karena prebiotik berfungsi sebagai sumber energi siap pakai dan tersedia di dalam saluran cerna sehingga probiotik dapat bertahan lebih lama dan berfungsi serta bekerja secara maksimal.

Pengamatan proporsi limfosit dalam darah mengalami penurunan setelah dilakukan penginfeksian pada ikan nila dengan $S$. agalactiae, baik pada perlakuan yang diberi penambahan probiotik $B$. cereus dan prebiotik maupun kontrol. Proporsi limfosit menurun karena antibodi digunakan untuk menyerang S. agalactiae, hal ini diduga karena pada saat setelah diinfeksi bakteri terjadi aktivitas perlawanan dari leukosit terhadap S. agalactiae. Peningkatan intensitas infeksi oleh patogen 
Tabel 1. Persentase diferensial leukosit ikan nila (O. niloticus)

Table 1. Differential leucocyt percentage of tilapia (O. niloticus)

\begin{tabular}{|c|c|c|c|c|}
\hline \multicolumn{5}{|c|}{$\begin{array}{l}\text { Rataan jumlah limfosit, monosit, dan neut rofil } \\
\text { Average num ber of lymphosit, monocyte, and neut rofil (\%) }\end{array}$} \\
\hline \multirow{2}{*}{$\begin{array}{l}\text { Parameter } \\
\text { Parameters }\end{array}$} & \multirow{2}{*}{$\begin{array}{l}\text { Perlakuan } \\
\text { Treatments }\end{array}$} & \multicolumn{3}{|c|}{$\begin{array}{l}\text { Pengamatan } \\
\text { Observation }\end{array}$} \\
\hline & & so & S 1 & S2 \\
\hline \multirow{4}{*}{$\begin{array}{l}\text { Limfosit } \\
\text { Lymphosit }\end{array}$} & A & \multirow{4}{*}{72.0} & 61.5 & 51.5 \\
\hline & B & & 62.5 & 49.0 \\
\hline & C & & 61.0 & 47.5 \\
\hline & D & & 62.0 & 48.0 \\
\hline \multirow{4}{*}{$\begin{array}{l}\text { Monosit } \\
\text { Monocyte }\end{array}$} & $A$ & \multirow{4}{*}{19.5} & 21.0 & 22.0 \\
\hline & B & & 20.0 & 21.5 \\
\hline & C & & 20.0 & 21.5 \\
\hline & $D$ & & 19.0 & 20.5 \\
\hline \multirow{4}{*}{$\begin{array}{l}\text { Neutrofil } \\
\text { Neutrofil }\end{array}$} & A & \multirow{4}{*}{8.5} & 17.5 & 26.5 \\
\hline & B & & 17.5 & 29.5 \\
\hline & $C$ & & 19.0 & 31.0 \\
\hline & $\mathrm{D}$ & & 19.0 & 31.5 \\
\hline
\end{tabular}

Keterangan (Remark):

$\mathrm{S} 0=$ Sebelum perlakuan (Before treatment); $\mathrm{S} 1$ = Setelah perlakuan (After treat ment); S2 = Pasca uji tantang minggu ke-2 (After challenge test on week 2)

tertentu akan memicu peningkatan kebutuhan leukosit dan peningkatan kebutuhan tersebut mengakibatkan adanya pengurangan jumlah sel agen penyedia zat kebal tubuh yaitu limfosit (Herlina, 2007).

Jumlah neutrofil meningkat pada saat pengamatan pasca uji tantang minggu ke-2. Peningkatan proporsi neutrofil ini berhubungan dengan respons melawan partikel asing yang masuk. Neutrofil merupakan garis pertahanan pertama yang bergerak cepat ke arah bahan asing dan menghancurkannya (Tizard, 1988). Monosit masuk ke dalam jaringan, berdiferensiasi menjadi makrofag sehingga jumlah monosit berfluktuasi dalam darah. Kebutuhan monosit pada saat infeksi untuk memfagosit S. agalactiae sangat diperlukan, sehingga jumlahnya akan meningkat supaya dapat melakukan aktivitas perlawanan dalam mencukupi kebutuhan sel-sel fagosit. Persentase monosit semua perlakuan pada masa pengamatan pasca uji tantang minggu ke-1 meningkat dengan persentase monosit berkisar 26,5\%-31,5\%. Proporsi monosit dalam leukosit hanya sebesar $0,1 \%$ dan meningkat sekitar $38 \%$ dalam waktu singkat bila terjadi infeksi (Lucky, 1977 dalam Herlina, 2007).

Sistem imun non spesifik merupakan sistem pertahanan penting dan bersifat dasar bagi invertebrata khususnya pada ikan. Probiotik di dalam penelitian dapat memperbaiki parameter imunologi pada ikan nila, terutama dengan melihat peningkatan pertumbuhan yang secara tidak langsung diakibatkan oleh peningkatan respons imun. Hal ini sesuai dengan penelitian Wang et al. (2008) menggunakan probiotik Enterococcus faecium pada ikan tilapia (Oreochromis niloticus) untuk meningkatkan pertumbuhan dan respons imun dan ternyata komplemen, aktivitas serum myeloperoksidase (MPO), serta aktivitas respiratory burst lebih tinggi daripada ikan kontrol.

\section{Indeks Fagosit}

Leukosit merupakan salah satu komponen darah yang berfungsi sebagai pertahanan nonspesifik yang akan melokalisasi dan meng- 
eliminasi patogen melalui fagositosis (Anderson, 1992). Meningkatnya indeks fagositosis menunjukkan adanya peningkatan kekebalan tubuh (Brown, 2000).

Berdasarkan hasil pengamatan bahwa indeks fagositosis dalam darah ikan uji yang diberi penambahan probiotik $B$. cereus (B dan D) lebih tinggi dibandingkan dengan ikan kontrol (A) dan ikan dengan penambahan prebiotik (C) (Tabel 2). Penambahan prebiotik akan menjadi makanan bagi probiotik dalam usus ikan sehingga nilai indeks fagosit pada ikan dengan penambahan sinbiotik (D) juga tinggi. Meningkatnya ketahanan tubuh dapat diketahui dengan meningkatnya aktivitas fagosit (Herlina, 2007). Maka terlihat dengan penambahan probiotik melalui pakan mampu meningkatkan nilai indeks fagosit dan meningkatkan sistem imun yang akhirnya nilai sintasan ikan pada perlakuan penambahan probiotik (B dan D) lebih tinggi dibandingkan pada ikan kontrol (A) dan ikan dengan pakan yang ditambah prebiotik saja (C) (Tabel 2).

$\mathrm{Hal}$ ini diduga karena probiotik B. cereus masuk ke dalam tubuh ikan melalui pakan ini di dalam usus terjadi kompetisi nutrien atau ruang antara probiotik dengan bakteri patogen. Ikan pada perlakuan kontrol (A), sel fagositnya tidak bekerja dengan baik sehingga ikan mudah sekali terinfeksi S. agalactiae, hal ini menyebabkan sintasan ikan nila sangat rendah mencapai 48,33\%.

Sel-sel fagosit ini berfungsi untuk melakukan fagositosis terhadap benda asing yang masuk ke dalam tubuh inang. Fagositosis

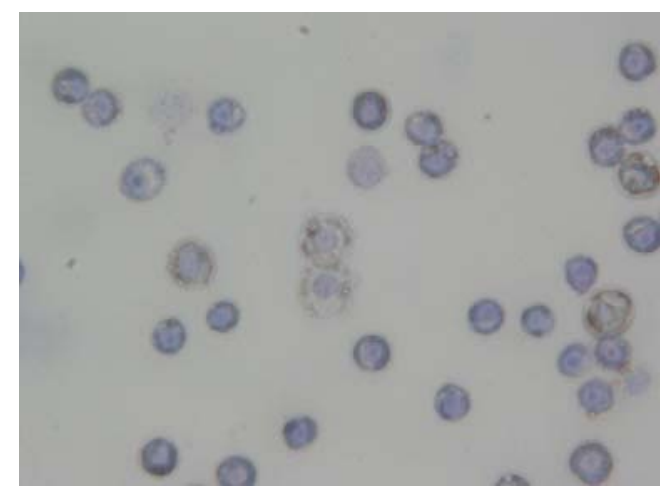

Gambar 3. Fagositosis antigen oleh sel fagosit pasca uji tantang (pembesaran 100x)

Figure 3. Antigen phagocytosis by phagocyte cell post challenge test (100x magnificent)

merupakan mekanisme pertahanan nonspesifik yang secara umum mampu melindungi adanya serangan penyakit. Sel fagosit ini berfungsi untuk melakukan fagositosis terhadap benda asing yang masuk ke dalam tubuh inang. Pola peningkatan persentase indeks fagositik ini merupakan fungsi dari peningkatan total leukosit maupun presentasi jenis leukosit masing-masing pada limfosit, monosit, dan neutrofil (Herlina, 2007).

Indeks fagositosis setelah uji tantang mengalami peningkatan baik pada ikan dengan perlakuan penambahan probiotik dan prebiotik (B, C, dan D) maupun kontrol (A). Peningkatan

Tabel 2. Rata-rata nilai fagositosis ikan uji

Table 2. Phagocytosis average value of fish sample

\begin{tabular}{ccccc}
\hline \multirow{2}{*}{$\begin{array}{c}\text { Perlakuan } \\
\text { Treatments }\end{array}$} & \multicolumn{4}{c}{$\begin{array}{c}\text { Rataan nilai fagositosis } \\
\text { Phagocytosis average value (\%) }\end{array}$} \\
\cline { 2 - 5 } & S0 & S1 & S2 & S3 \\
\hline A & & 15.5 & 20.5 & 30.5 \\
B & 9.9 & 30.5 & 50.5 & 65.5 \\
C & & 20.0 & 41.0 & 52.0 \\
D & & 51.5 & 60.5 & 70.0 \\
\hline
\end{tabular}

Keterangan (Remark):

S0 = Sebelum perlakuan (Before treatment); S1 = Setelah perlakuan (After treatment); S2 = Pengamatan pasca uji tantang minggu 1 (Week 1 observation after challenge test); S3 = Pengamatan pasca uji tantang minggu 2 (Week 2 observation after challenge test) 
aktivitas fagositik diduga karena adanya infeksi S. agalactiae yang menyebabkan beban kerja sel fagositik menjadi lebih besar, sehingga kemampuan memfagositosis bakteri mengalami peningkatan dan jumlah sel yang memfagosit mengalami peningkatan. Gill \& Martin (2002) menyatakan bahwa pada mamalia bakteri probiotik dapat menstimulir respons imun melalui interaksi dengan sistem imun di dalam pencernaan (usus). Mekanisme interaksi bakteri probiotik dan sistem imun dalam usus terjadi pada bagian peyer"s patches yaitu bagian yang terletak di antara vili-vili usus yang berbentuk oval dan di dalamnya kaya akan limfosit dan makrofag. Bakteri probiotik akan dibawa menuju peyer's patches yang kemudian akan menstimulasi limfosit B membentuk IgM menjadi IgA dan menstimulasi peningkatan jumlah sitokin (IL-4, IL-6, TGF- $\beta$, dan TNF). Interaksi bakteri probiotik juga akan menstimulasi sel $\mathrm{T}$ pembentuk sel Th yang akan mengaktifkan makrofag untuk memusnahkan bakteri patogen. Sitokin, IgA, dan makrofag yang diaktivasi oleh bakteri probiotik akan dibawa menuju nodus limfoid mesentrik kemudian menuju ke seluruh jaringan.

Stimulasi respons imun oleh bakteri probiotik di dalam saluran pencernaan ikan berbeda dengan mamalia (Nayak, 2010). Ikan tidak memiliki peyer's patches, tetapi terdapat sel yang berfungsi sebagai sistem imun yaitu sel acidophilic granulocytes (AGs), sel Ig+, sel $\mathrm{T}$, makrofag, granulosit, dan IgM. Interaksi bakteri probiotik di dalam saluran pencernaan dapat meningkatkan dan mengaktivasi sel-sel sistem imun tersebut, kemudian akan masuk ke pembuluh darah dan terbawa ke jaringan untuk meningkatkan respons di seluruh tubuh ikan.

\section{Gejala Klinis}

Pengamatan gejala klinis ikan nila dilakukan setelah dilakukan uji tantang dengan $S$. agalactiae dengan kepadatan $10^{3} \mathrm{CFU} / \mathrm{mL}$ sebanyak $0,1 \mathrm{~mL}$. Gejala klinis awal terlihat jelas berupa melanosis, berenang terbalik (whirling), dan mata mengalami eksopthalmus lateral maupun bilateral pada ikan kontrol (A), ikan dengan penambahan probiotik $B$. cereus (B), dan ikan dengan penambahan prebiotik (C), sedangkan ikan pada perlakuan penambahan sinbiotik (D) tidak menunjukkan gejala klinis. Penambahan sinbiotik menunjukkan kemampuan menahan serangan awal akibat infeksi S. agalactiae. Pada 6 jam pertama sampai 24 jam penginfeksian, gejala klinis yang timbul belum terlihat. Terjadinya proses penghambatan sementara ini mengindikasikan bahwa dengan penambahan probiotik yang dikombinasi dengan prebiotik dapat meningkatkan daya tahan tubuh ikan nila, serta menghambat serangan $S$. agalactiae yang menginfeksi ikan nila sehingga dapat meningkatkan sintasan ikan nila.

Kerusakan jaringan tubuh pertama kali muncul setelah 36 jam penginfeksian $S$. agalactiae, yang ditandai dengan gerak renang tubuh ikan yang abnormal dan sulit bernafas serta terjadi perubahan pigmentasi tubuh ikan. Pada hari ke-2 sampai hari ke-11 setelah diuji tantang, ikan nila mulai timbul gejala klinis. Gejala klinis terlihat jelas pada ikan kontrol (A) dibandingkan dengan perlakuan yang diberi probiotik dan prebiotik (B, C, dan D). Kerusakan jaringan mata ikan nila ini diduga akibat toksin yang dikeluarkan oleh S. agalactiae yang terbawa aliran darah ke seluruh tubuh dan langsung menginfeksi jaringan mata ikan dan terjadi eksopthalmia (Gambar 4).

Pada hari ke-12 sampai dengan ke-14 setelah penginfeksian kondisi ikan nila berangsur-angsur membaik, hal ini terlihat dari respons makan ikan dan pergerakan renang ikan yang kembali normal. Hal ini disebabkan karena sistem imun ikan terutama non-spesifik mampu menanggulangi infeksi patogen di dalam tubuh. Probiotik dapat membantu tubuh untuk meningkatkan kemampuan sistem imun non-spesifik untuk aktif di dalam proses fagositosis patogen apalagi jika tersedia prebiotik, maka peran probiotik menjadi lebih maksimal.

\section{Kualitas Air}

Nilai parameter kualitas air media pemeliharaan selama penelitian berada pada kisaran yang sesuai untuk pemeliharaan ikan nila (Tabel 3). Hal ini menunjukkan bahwa hasil penelitian yang diperoleh disebabkan adanya perbedaan perlakuan dan bukan merupakan pengaruh dari kualitas air.

Selama penelitian dilakukan pengukuran terhadap beberapa parameter kualitas air yaitu: suhu, $\mathrm{pH}, \mathrm{DO}$, dan $\mathrm{NH}_{3}$. Pengamatan kualitas air digunakan sebagai parameter pendukung selama penelitian. Pengamatan diuji pada awal penelitian, tengah, dan akhir penelitian.

Berdasarkan hasil pengukuran kualitas air selama penelitian menunjukkan bahwa nilai 

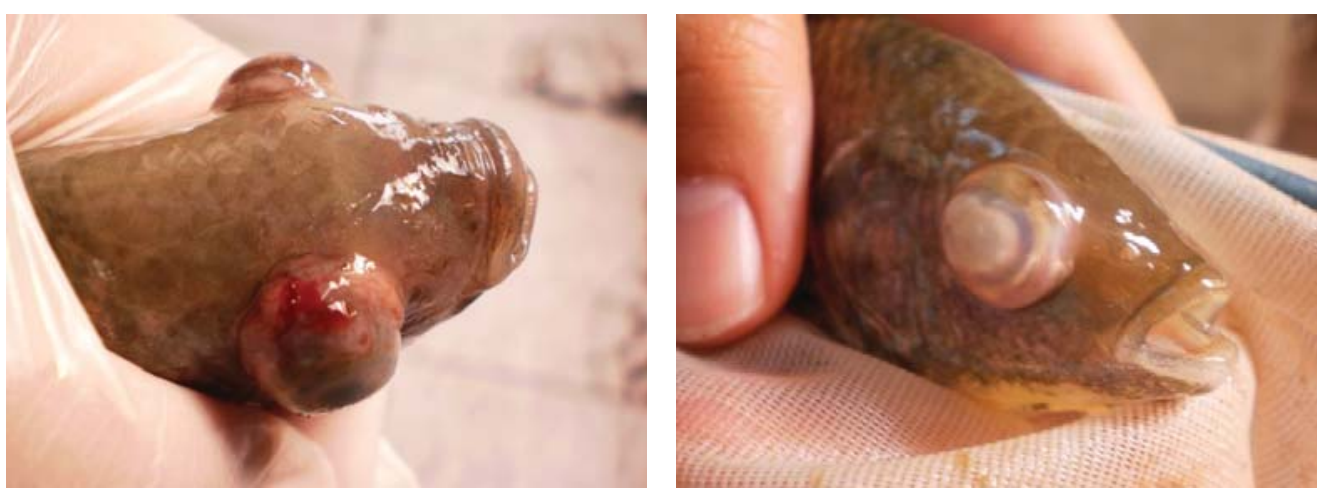

Gambar 4. Pendarahan kornea dan eksopthalmia pada ikan nila yang terinfeksi S. agalactiae

Figure 4. Cornea haemorrhagiae and exopthalmia on $\boldsymbol{O}$. niloticus infected because of $\boldsymbol{S}$. agalactiae

Tabel 3. Nilai kualitas air media pemeliharaan O. niloticus dengan perlakuan yang berbeda selama penelitian

Table 3. Value of water quality maintenance $\boldsymbol{O}$. niloticus cultured with different treatments

\begin{tabular}{|c|c|c|c|c|c|}
\hline \multirow{2}{*}{ Sampling } & \multirow{2}{*}{$\begin{array}{l}\text { Perlakuan } \\
\text { Treatments }\end{array}$} & \multicolumn{4}{|c|}{$\begin{array}{l}\text { Nilai parameter kualitas air yang diamat } \mathrm{i} \\
\text { The observation of water quality values }\end{array}$} \\
\hline & & pH & $\begin{array}{c}\text { Amonia } \\
\text { Am monia } \\
(\mathrm{mg} / \mathrm{L})\end{array}$ & $\begin{array}{c}\text { Suhu } \\
\text { Temperat ure } \\
\left({ }^{\circ} \mathrm{C}\right)\end{array}$ & $\begin{array}{c}\mathrm{DO} \\
(\mathrm{mg} / \mathrm{L})\end{array}$ \\
\hline \multicolumn{6}{|l|}{$\begin{array}{l}\text { So } \\
\text { Awal } \\
\text { Beginning }\end{array}$} \\
\hline \multirow{4}{*}{$\begin{array}{l}\text { S } 1 \\
\text { Tengah } \\
\text { Middle }\end{array}$} & $A$ & 7.63 & 0.089 & 27.2 & 4.64 \\
\hline & B & 7.32 & 0.083 & 27.2 & 2.95 \\
\hline & $C$ & 7.19 & 0.026 & 27.2 & 2.79 \\
\hline & D & 7.37 & 0.086 & 27.6 & 4.45 \\
\hline \multirow{4}{*}{$\begin{array}{l}\mathrm{S} 2 \\
\text { Akhir (End) }\end{array}$} & A & 7.57 & 0.013 & 27.5 & 4.45 \\
\hline & B & 7.20 & 0.00456 & 26.8 & 3.13 \\
\hline & $\mathrm{C}$ & 7.23 & 0.0055 & 27.5 & 2.85 \\
\hline & $\mathrm{D}$ & 7.36 & 0.0056 & 27.2 & 4.54 \\
\hline \multicolumn{2}{|c|}{$\begin{array}{l}\text { Standar optimum } \\
\text { Optimum standard }\end{array}$} & $\begin{array}{c}6.5-9 \\
\text { Boyd (1982) }\end{array}$ & $\begin{array}{c}<0.1 \\
\text { Cahyono }(2000)\end{array}$ & $\begin{array}{c}14-35 \\
\text { Boyd (1982) }\end{array}$ & $\begin{array}{l}\text { Minimal } 2 \\
\text { Boyd (1982) }\end{array}$ \\
\hline
\end{tabular}

kualitas air yang diperoleh berada dalam kisaran yang optimum untuk pertumbuhan ikan nila. Hal ini sesuai dengan pernyataan Boyd (1982) dan Cahyono (2000). Berdasarkan hasil pengukuran kualitas air memperlihatkan bahwa penambahan bakteri probiotik Bacillus sp. yang dikombinasikan dengan ekstrak tepung ubi jalar (prebiotik) ke dalam pakan komersial dapat mempertahankan ketahanan tubuh ikan dan menjaga kualitas air media pemeliharaan ikan nila. Dengan demikian, dapat dikemukakan bahwa kualitas air masih dalam batas toleransi 
untuk budidaya ikan nila, sehingga kematian ikan nila bukan akibat kualitas air yang tidak sesuai, tetapi oleh aktivitas S. agalactiae.

\section{KESIMPULAN DAN SARAN}

\section{Kesimpulan}

Berdasarkan data hasil penelitian dapat disimpulkan bahwa pemberian 1\% probiotik Bacillus cereus dan prebiotik (ekstrak tepung ubi jalar) 2\% (sinbiotik) ke dalam pakan komersial dapat meningkatkan rata-rata sintasan ikan nila sebesar 70,00\%; kadar neutrofil 19\%; dan aktivitas fagosit sebesar $51,5 \%$ setelah diuji tantang dengan Streptococcus agalactiae yang lebih baik jika dibandingkan dengan kontrol, probiotik, dan prebiotik saja dengan tingkat sintasan masing-masing 48,33\%; $56,67 \%$; dan $60 \%$.

\section{Saran}

Perlu dilakukan uji skala lapang penambahan 1\% probiotik Bacillus cereus yang dicampur $2 \%$ prebiotik ekstrak tepung ubi jalar (sinbiotik) ke dalam pakan komersial.

\section{DAFTAR ACUAN}

Anderson, D.P. 1992. Fish Immunology. In Snieszko \& H.R. Axelord (Eds.). Disease of Fishes. TFH Publication. England, 185 pp.

Baya, A.M., Lupiani, B., Hetrick, F.M., Robertson, B.S., Lucacovic, R., May, E., \& Puokish, C. 1990. Association of Streptococcus sp. with mortalities in the Chesapeake bay and it's tributaries. J. of Fish Dis., 13: 251-253.

Boyd, C.E. 1982. Water quality management for pond fish culture. Elsevier Scientific Publishing Company. Amsterdam, 319 pp.

Brown. 2000. Applied Fish Pharmacology. Kluwer Academic Publisher. Netherland, 309 pp.

Cahyono, B. 2000. Budidaya ikan air tawar (ikan gurami, ikan nila, ikan mas). Penerbit Kanisius. Yogyakarta, $87 \mathrm{hlm}$.

Chang, P.H. \& Plumb, J.A. 1996. Histopatology of eksperimental Streptococcus sp. infection in tilapia. Oreochromis niloticus (L.) and chanel catfish, Ichtalurus punctatus (Rafinesque). J. of Fish Dis., 19: 235-241.

Gasperz, V. 1991. Metode perancangan percobaan untuk ilmu-ilmu pertanian, Ilmuilmu Teknik dan Biologi. Armico Bandung, $472 \mathrm{hlm}$.
Gill, H.S. \& Martin, L.C. 2002. Probiotic and immune function. In Calder, P.C., Catherine, J.F., \& Gill, H.S. (Eds.) Nutrition and Immune Function. Cabi Publishing, 105 pp.

Herlina, T. 2007. Gambaran darah pada ikan mas (Cyprinus carpio L.) yang terserang berbagai jenis golongan penyakit berdasarkan analisis hematologi darah dan diferensiasi leukosit. Stasiun Karantina Ikan Kelas II Bengkulu, $85 \mathrm{hlm}$.

Lusiastuti, A.M., Condro, A.H., Sumiati, T., Wijaya, A., \& Sularto. 2011 . Uji seleksi probion anti Streptococcus agalactiae untuk formulasi sediaan monospesies dan multispesies. Prosiding Forum Inovasi Teknologi Akuakultur Jilid 2, Bali, 19-21 Juli 201 1, hlm. 639647.

Mahious, A.S., Gatesoupe, F.J., Hervi, M., Metailler, R., \& Ollevier, F. 2006. Effect of dietary inulin and oligosaccharides as prebiotics for weaning turbot, Psetta maxima. J. of Aquaculture International, 14(3): 219-229.

Nayak, S.K. 2010. Probiotics and immunity: A fish perspective. J. Fish and Shellfish Immunology, 29: 2-14.

Purwanto, A. 2006. Gambaran darah ikan mas (Cyprinus carpio) yang terinfeksi koi herpes virus. Skripsi. Program Studi Teknologi dan Manajemen Akuakultur. FPIK Institut Pertanian Bogor, $26 \mathrm{hlm}$.

Salasia, S.I.O., Sulanjari, D., \& Ratnawati, A. 2001. Studi hematologi ikan air tawar. Biologi, 2(12): 710-723.

Short, S., Ouwehand, A.C., \& Salminen, S. 1999. Probiotics: mechanism and established effects. Int. Dairy Journal, 9: 43-52.

Sumiarti, H. 2000. Pengaruh antibiotik neomycin terhadap sintasan ikan nila gift dalam menanggulangi Streptococciasis. Skripsi. Fakultas Perikanan dan Ilmu Kelautan Universitas Padjajaran Bandung, $84 \mathrm{hlm}$.

Taukhid. 2009. Efektivitas pemberian vaksin Streptococcus spp. pada benih ikan nila (Oreochromis niloticus) melalui teknik perendaman untuk mencegah penyakit Streptococciasis. Laporan Penelitian Hibah Penelitian bagi Peneliti dan Perekayasa Departemen Kelautan dan Perikanan, Balai Riset Perikanan Budidaya Air Tawar, Pusat Riset Perikanan Budidaya, $33 \mathrm{hlm}$.

Tizard, I. 1988. Pengantar imunologi veteriner. Edisi ke-2. Partodirejo, M. Hardjosworo, S. Penerjemah: Surabaya, Airlangga University 
Press. Terjemahan dari: An Introduction to Veterinary Immunology, $152 \mathrm{hlm}$.

Verschuere, L., Rombaut, G., Sorgeloos, P., \& Verstraete, W. 2000. Probiotic bacteria as biological control agents in aquaculture. Microbiol. Mo. Biol. Rev., 64: 655-671.
Wang, Y.B., Tian, Z.Q., Yao, J.T., \& Li, W.F. 2008. Effect of probiotics, Enterococcus faecium, on tilapia (Oreochromis niloticus) growth performance and immune response. Aquaculture, 277: 203-207. 